\title{
NICKEL BIOSORPTION BY ACINETOBACTER BAUMANNII AND PSEUDOMONAS AERUGINOSA ISOLATED FROM INDUSTRIAL WASTEWATER
}

\author{
Carlos E. Rodríguez ${ }^{1 *}$; Adolfo Quesada²; Evelyn Rodríguez ${ }^{1}$
}

${ }^{1}$ Laboratorio de Investigación en Bacteriología Anaerobia y Centro de Investigación en Enfermedades Tropicales, Facultad de Microbiología, Universidad de Costa Rica; ${ }^{2}$ Facultad de Microbiología, Universidad de Costa Rica.

Submitted: August 17, 2005; Returned to authors for corrections: January 11, 2006; Approved: July 18, 2006

\section{SHORT COMMUNICATION}

\begin{abstract}
Nickel biosorption ability was evaluated in two bacterial strains: Acinetobacter baumannii UCR-2971 and Pseudomonas aeruginosa UCR-2957, resulting in greatest adsorption at $\mathrm{pH} 4.5$ and a residence time of 100 minutes. Biosorption isotherms showed that the process follows the Langmuir model. The maximum adsorption rates $\left(N_{\max }\right)$ were 8.8 and $5.7 \mathrm{mg} \cdot \mathrm{g}^{-1}$ for $A$. baumannii and $P$. aeruginosa, respectively; however, affinity constants suggest that $P$. aeruginosa $(K=1.28)$ has higher affinity for nickel than $A$. baumannii $(K=0.68)$. It is suggested that both strains could be used for wastewater treatment, as long as the concentration of $\mathrm{Ni}^{2+}$ is within the range of $\mathrm{mg} \cdot \mathrm{L}^{-1}$.
\end{abstract}

Key words: biosorption, nickel, Acinetobacter baumannii, Pseudomonas aeruginosa, wastewater treatment

Nickel is an important environmental inorganic pollutant, with allowed levels under $0.04 \mathrm{mg} \cdot \mathrm{L}^{-1}$ in human consumption water. Higher concentrations affect normal flora in ecosystems and are toxic for human beings.

Conventional chemical methods for heavy metal removal from wastewater (precipitation, filtration, ion-exchange, reduction-oxidation) are expensive and ineffective, particularly when metal concentration is low $(4,12,13)$. Thus, biotechnological methods such as biosorption are emerging as an interesting alternative. Since cells are metabolically inactive in non-viable biomass systems, metal interactions occur at the superficial level (14). Bacteria express a wide range of complex molecules on their cell wall, which confer anionic net charge to the cell surface at acidic $\mathrm{pH}$ values (13). In Gram negative bacteria, the lipopolysaccharide, a highly anionic structure, has been identified as the main binding site for metals (9). When the cell wall is in direct contact with the environment, negatively charged groups are able to attract and bind metallic cations based on electrostatic forces, without cellular energy consumption, an effect that is favored by the high surfacevolume ratio in bacteria $(3,5)$.

In this work, nickel biosorption ability was investigated using bacteria isolated from wastewater contaminated with heavy metals ( $\left.34.9 \pm 9.0 \mathrm{mg} \mathrm{Ni}^{2+} \cdot \mathrm{L}^{-1} ; 31.5 \pm 4.0 \mathrm{mg} \mathrm{Pb} \cdot \mathrm{L}^{-1}\right)$. The sample was aseptically filtered $(0.45 \mu \mathrm{m}$ membrane); the residues were resuspended in $100 \mathrm{~mL}$ Trypticase Soybean Broth (TSB, Difco) and incubated at $25^{\circ} \mathrm{C}$ for four days. Then, $0.1 \mathrm{~mL}$ from the TSB were inoculated in Blood Agar, Cetrimide Agar (Difco), and Mac Conkey Agar (Oxoid) plates and incubated for 48 hours at $25^{\circ} \mathrm{C}$. Isolated strains were identified using the automatic VITEK system (BioMèrieux, Inc); Acinetobacter baumannii (UCR-2971) and Pseudomonas aeruginosa (UCR-2957) were the selected strains. For biomass production, these strains were inoculated in TSB and agitated (80 rpm) in a thermal bath (Orbit 3540, Labline), for 72 hours at $28^{\circ} \mathrm{C}$. The TSB was centrifuged at $5000 \mathrm{rpm}$ for 10 minutes and biomass was washed three times with sterile distilled water and dried at $56^{\circ} \mathrm{C}$ for 48 hours. The inocula of each adsorption

*Corresponding Author. Mailing address: Facultad de Microbiología, Universidad de Costa Rica, Costa Rica, C.A. Tel.: (+506) 207-4364. Fax: (+506) 225-4384. E-mail: cerodri@ cariari.ucr.ac.cr 
assay were prepared by suspending $5.0 \mathrm{mg}$ of dry biomass in $0.5 \mathrm{~mL}$ of sterile saline solution $(0.9 \%)$.

To determine optimal adsorption conditions, a series of flasks containing $100 \mathrm{~mL}$ of an initial solution of $\mathrm{Ni}^{2+}(1.00 \pm 0.01$ $\left.\mathrm{mg} \cdot \mathrm{L}^{-1}\right)$ were inoculated with each strain and maintained in agitated bath $(80 \mathrm{rpm})$ at $28^{\circ} \mathrm{C}$. Three values of $\mathrm{pH}(2.5,3.5$ and $4.5)$ and four residence times (60, 80, 100 and 120 minutes) were evaluated. After that, $12 \mathrm{~mL}$ of each flask were centrifuged 10 minutes at $1500 \mathrm{rpm}$ and the final concentration of $\mathrm{Ni}^{2+}$ was determined in the supernatant by atomic absorption spectroscopy (Perkin Elmer model 3300), according to the methodology recommended by APHA (1).

The assays were repeated at optimal conditions $(\mathrm{pH} 4.5$ and residence time 100 minutes) with $\mathrm{Ni}^{2+}$ solutions of $1.00,0.80$, $0.60,0.50,0.40( \pm 0.01) \mathrm{mg} \cdot \mathrm{L}^{-1}$, in order to obtain adsorption curves, which were adjusted to Langmuir lineal model of isotherms by the equation

$$
\frac{C_{f}}{N}=\frac{C_{f}}{N_{\max }}+\frac{1}{K N_{\max }}
$$

where $N$ is the capture of nickel $\left(\mathrm{mg} \cdot \mathrm{g}^{-1}\right), N_{\max }$ the maximum capture of the metal $\left(\mathrm{mg}^{-1} \mathrm{~g}^{-1}\right), C_{f}$ the final concentration in the solution $\left(\mathrm{mg} \cdot \mathrm{L}^{-1}\right)$ and $K$ is a constant related to the affinity between the metal and the biomass $(2,7,8,14)$.

Optimum $\mathrm{pH}$ values for bacteria biosorption are acidic, since the cell wall keeps negatively charged (13). $\mathrm{pH}$ values above 5 are known to result in nickel precipitation (14) and therefore were not evaluated. For both strains, an increment of $\mathrm{Ni}^{2+}$ adsorption was observed, as the solution $\mathrm{pH}$ increased from 2.5 to 4.5 (Fig. 1). This might be explained because at very low $\mathrm{pH}$ values functional anionic groups could be bound to hydronium ions $\left(\mathrm{H}_{3} \mathrm{O}^{+}\right)$, leading to restriction of cation uptake as result of charge-repulsion forces, which become stronger as $\mathrm{pH}$ decreases $(2,12)$. In similar studies with other metal cations, Malekzadeh et al. (11) isolated a strain of Pseudomonas sp. highly capable of accumulating uranium at $\mathrm{pH} 6.5$; also, Leung et al. (10) found that lead and copper uptake by $P$. pseudoalcaligenes and Micrococcus luteus increases as $\mathrm{pH}$ values raise from 2 to 6 .

Optimum $\mathrm{pH}$ value for nickel adsorption was 4.5 , with optimum residence time of 100 minutes for both strains (Fig. 1); once this time elapsed, uptake diminished, which agrees with biosorption models, where the process can be considered as an equilibrium that involves adsorption and desorption, due to saturation (12). Similar studies report maximum nickel adsorption at $\mathrm{pH} 5$ and optimum residence times of 100 and 120 minutes for nickel uptake by different microorganisms $(2,12,14)$.

Biosorption kinetics has not been completely defined, but some authors propose that it follows a pattern close to the empiric model described by Langmuir $(2,6,7,8,15)$. The high correlation coefficients obtained from linear regression of
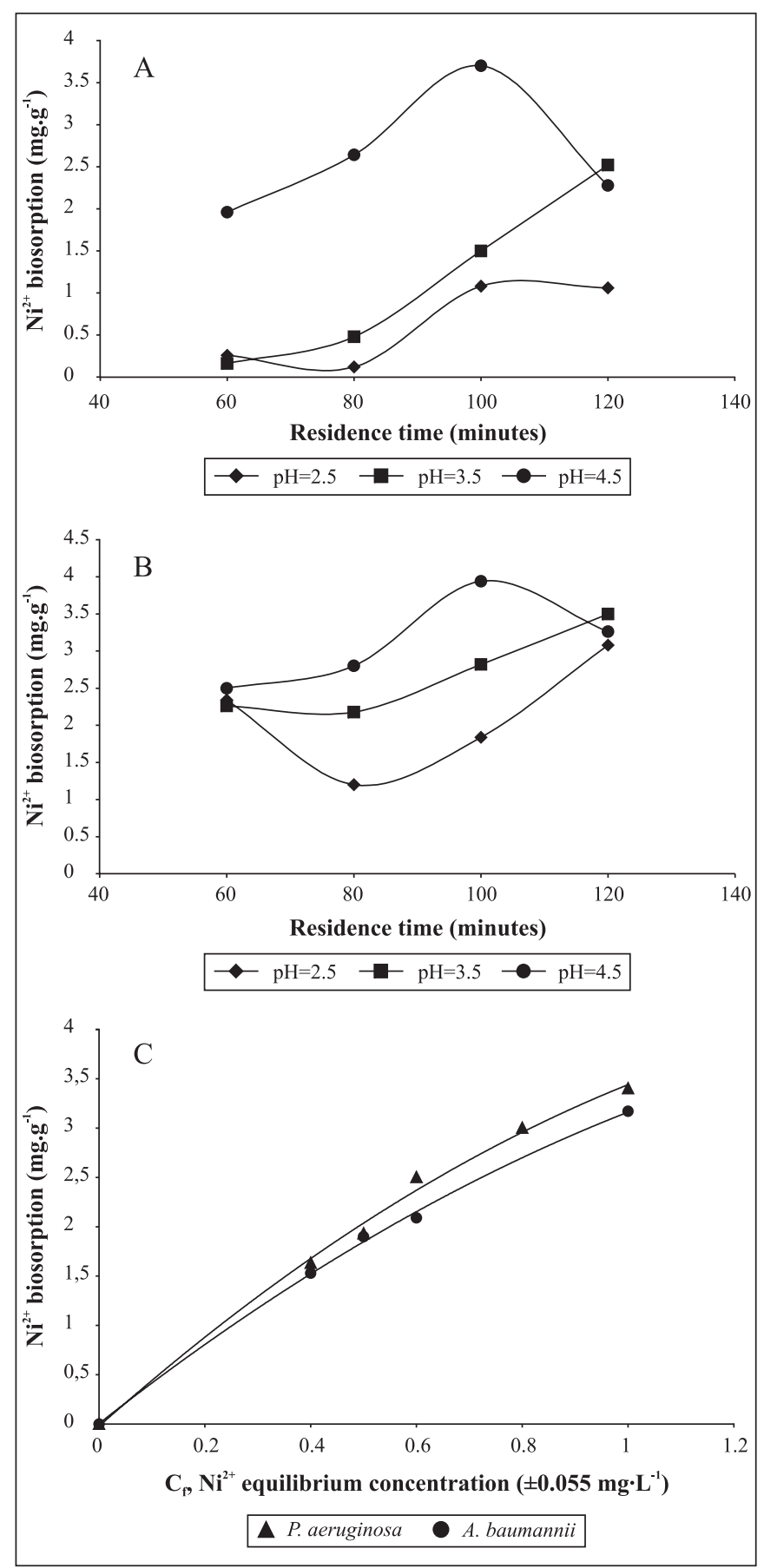

Figure 1: Effect of $\mathrm{pH}$ and residence time on $\mathrm{Ni}^{2+}$ biosorption in (A) Acinetobacter baumannii UCR-2971 and (B) Pseudomonas aeruginosa UCR-2957. (C) Adsorption isotherms (pH 4.5, residence time: $100 \mathrm{~min}, 28^{\circ} \mathrm{C}$ ).

isotherms ( $\mathrm{r}=0.9838$ for $P$. aeruginosa; $\mathrm{r}=0.9804$ for $A$. baumannii) show that experimental adsorption kinetics for these strains can be adequately described applying Langmuir 
isotherms. This allowed to determine the maximum nickel uptake $\left(N_{\max }\right): 8.8 \mathrm{mg} \cdot \mathrm{g}^{-1}$ and $5.7 \mathrm{mg} \cdot \mathrm{g}^{-1}$, and the affinity constant between metal and biomass $(K)$ : 0.68 and 1.28 for $A$. baumannii and $P$. aeruginosa, respectively. These results show that $A$. baumannii has a higher ability to uptake $\mathrm{Ni}^{2+}$ than $P$. aeruginosa, although affinity for nickel ions is higher in the latter. These findings suggest that $P$. aeruginosa could have a lower number of wall binding sites to interact with $\mathrm{Ni}^{2+}$, but with a stronger binding to this metal, compared to A. baumannii.

Previous studies with $P$. aeruginosa report higher adsorption rates for other metals (4); there are no reports concerning biosorption by Acinetobacter sp. Nickel uptake has been reported in Phanerochaete chrysosporium $\left(N_{\max }=55.9\right.$ $\left.\mathrm{mg} \cdot \mathrm{g}^{-1}\right)$, Aspergillus niger $\left(N_{\max }=14.1 \mathrm{mg} \cdot \mathrm{g}^{-1}\right)$ and a hyper accumulator strain of Bacillus sp. $\left(N_{\max }=244 \mathrm{mg} \cdot \mathrm{g}^{-1}\right)(6,14,15)$.

Results obtained in the present study indicate that $4.0 \mathrm{~g} \cdot \mathrm{L}^{-1}$ of A. baumannii and $6.1 \mathrm{~g} \cdot \mathrm{L}^{-1}$ of P. aeruginosa biomass would be theoretically necessary to remove all the nickel of the wastewater analyzed. Clearly, it would not be feasible to employ this kind of microbial biomass as the only method to eliminate nickel from wastewater contaminated with high concentrations of this metal ( $\mathrm{g} \cdot \mathrm{L}^{-1}$ or more), because such high levels would promote a faster saturation of binding sites, displacing the equilibrium towards a desorption process $(3,4,12,13)$. Nonetheless, this biomass could be applied in reactors after conventional chemical treatments, to further deplete the nickel content of some industrial wastewaters.

\section{ACKNOWLEDGEMENTS}

The authors would like to thank Dr. B. Lomonte for his critical review of this manuscript. This work was supported by the Vicerrectoría de Investigación of the Universidad de Costa Rica.

\section{RESUMO}

\section{Bioadsorção de niquel por Acinetobacter baumannii e Pseudomonas aeruginosa isoladas de águas residuais industriais}

Foi avaliada a capacidade de adsorção do $\mathrm{Ni}^{2+}$ por duas bactérias, Acinetobacter baumannii e Pseudomonas aeruginosa, em pH 4.5 com tempo de contato de 100 minutos. Isotermas de adsorção foram calculadas com as duas linhagens. Observou-se que, para ambas, o processo de adsorção está de acordo com o modelo fisicoquímico de Langmuir. A captação máxima do $\mathrm{Ni}^{2+}\left(N_{\text {max }}\right)$ foi $5.7 \mathrm{e} 8.8 \mathrm{mg} \mathrm{Ni}^{2+} \mathrm{g}^{-1}$ para $P$. aeruginosa e A. baumannii, respectivamente. Não obstante, $P$. aeruginosa apresenta uma constante de afinidade $(K=1.28)$ maior que $A$. baumannii $(K=0.68)$. Estes resultados indicam que ambas as linhagens são adequadas para o tratamento de águas contaminadas, desde que a concentração de níquel seja da ordem de $\mathrm{mg} \cdot \mathrm{L}^{-1}$.

Palavras-chave: bioadsorção, niquel, Acinetobacter baumannii, Pseudomonas aeruginosa, tratamento de águas residuais

\section{REFERENCES}

1. American Public Health Association. Standard Methods for the Examination of Water and Wastewater, 20th ed. APHA, Washington, 1998, 1220p.

2. Abu Al-Rub, E.A.; Ashour, I.; El-Naas, M.; Benyahia, F. Adsorption of nickel on immobilized algal biomass. The Fourth Annual UAE University Research Conference, UAE University, Al-Ain, 2003, p. 17-20.

3. Atkinson, B.W.; Bux, F.; Kasan, H.C. Considerations for application of biosorption technology to remediate metal-contaminated industrial effluents. Water SA, 24, 129-135, 1998.

4. Cañizares Villanueva, R.O. Bioadsorción de metales pesados mediante el uso de biomasa microbiana. Rev. Latinoam. Microbiol., 42, 131 143, 2000.

5. Erlich, H.L. Microbes and metals (Mini review). Appl. Microbiol. Biotechnol., 48, 687-692, 1997.

6. Filipoviæ-Kovaèeviæ, Z.; Sipos, L.; Briški, F. Biosorption of chromium, copper, nickel and zinc ions onto fungal pellets of Aspergillus niger 405 from aqueous solutions. Food Technol. Biotechnol., 38, 211-216, 2000.

7. Gomes, N.M.C.; Rosa, C.A.; Pimentel, P.F.; Mendonça-Hagler, L.C.S Uptake of free and complexed silver ions by different strains of Rhodotorula mucilaginosa. Braz. J. Microbiol., 33, 62-66, 2002.

8. Hussein, H.; Ibrahim, S.F.; Kandeel, K.; Moawad, H. Biosorption of heavy metals from waste water using Pseudomonas sp. Electron. J. Biotechnol., 7, 30-37, 2004.

9. Langley, S.; Beveridge, T.J. Effect of O-side chain-lipopolysaccharide chemistry on metal binding. Appl. Environ. Microbiol., 65, 489498, 1999.

10. Leung, W.C.; Wong, M.F.; Chua, H.; Lo, W.; Yu, P.H.; Leung, C.K. Removal and recovery of heavy metals by bacteria isolated from activated sludge treating industrial effluents and municipal wastewaters. Water Sci. Technol., 41, 233-240, 2000.

11. Malekzadeh, F.; Farazmand, A.; Ghafourian, H.; Shahamat, M.; Levin, M.; Grim, C.; Colwell, R.R. Accumulation of heavy metals by a bacterium isolated from electroplating effluent. Proceedings of the Biotechnology Risk Assessment Symposium, Canada, 1996, p.388398.

12. Panchanadikar, V.V. Biosorption process for removing lead (II) ions from aqueous effluents using Pseudomonas sp. Int. J. Environ. Studies, 46, 243-250, 1994

13. Vieira, R.; Volesky, B. Biosorption: a solution to pollution? Int. Microbiol., 3, 17-24, 2000.

14. Yetis, Ü.; Çeribasi, H. Biosorption of $\mathrm{Ni}$ (II) and $\mathrm{Pb}$ (II) by Phanerochaete chrysosporium from a binary metal system-Kinetics. Water SA, 27: 15-20, 2001.

15. Zaidi, S.; Musarrat, J. Characterization and nickel biosorption kinetics of a new hyper-accumulator Bacillus sp. J. Environ. Sci. Health, 39, 681-691, 2004. 